\title{
Serological Investigation of Newcastle Disease in Selected Districts of Buno Bedelle Zone, Ethiopia
}

\section{Tamirat Mamo' \\ Lama Yimer ${ }^{2}$}

'Seyo District Livestock Development Office, Dembi Dollo, Ethiopia; ${ }^{2}$ School of Veterinary Medicine, Wollega University, Nekemte, Ethiopia
Correspondence: Lama Yimer School of Veterinary Medicine, Wollega University, Nekemte, Ethiopia

Tel +25I 917081237

Email lemayimer@gmail.com
Purpose: Newcastle disease causes considerable loss in the poultry industry worldwide and its outbreaks are regularly reported from all continents of the world, including Ethiopia. The investigation was conducted from October 2020 to June 2021 to determine the prevalence of Newcastle disease (ND) in districts selected from Buno Bedele zone, Western Oromia.

Methods: The study design used was a cross-sectional type. For this study, a total of 480 serum samples were collected as per sample collection guideline from randomly selected chickens that were apparently healthy and had no history of vaccination against Newcastle disease. Indirect ELISA was performed and all data were analyzed using SPSS statistical software.

Results: From serological investigation, overall seroprevalence of Newcastle disease was $30 \%$. Seroprevalence of Newcastle disease was $34.94 \%, 22.22 \%$, and $31.76 \%$ in Didessa, Chora, and Gachi districts, respectively. Among computed risk factors, breed showed statistically significant difference and the odds of infection were lower in adult than in young chickens. Similarly, the odds of infection with Newcastle disease virus were significantly higher in crossbred than in locally bred backyard chickens.

Conclusion: This study revealed Newcastle disease was prevalent in the study areas; therefore, regular investigation of Newcastle disease should be conducted along with detailed studies on molecular characterization of circulating field strains in the area.

Keywords: Buno Bedele, Ethiopia, indirect ELISA, Newcastle disease

\section{Introduction}

Poultry in Ethiopia serves as critical contributor to food and nutrition security, and is a source of cash earning for a large part of the population. ${ }^{1,2}$ As in many developing countries, chickens are extensively kept in Ethiopia, ${ }^{3}$ with the overall population predicted to be approximately 60 million of which $90.8 \%, 4.4 \%$ and, $4.8 \%$ had been suggested to be indigenous, exotic and, hybrid, respectively. ${ }^{4}$

Poultry diseases are responsible for several adverse financial and social impact including mortality and morbidity of chickens, excessive medication costs, loss in manufacturing and marketing that could pose a risk to public health through zoonoses. $^{5}$ Newcastle disease is a highly contagious viral disease affecting wild and domestic avian species. ${ }^{6,7}$ It is caused by virulent viruses from the genus Avulavirus and species avian avulavirus 1, usually called Newcastle disease virus (NDV) and abbreviated as avian paramyxovirus 1 (APMV1). ${ }^{8,9}$

The Newcastle disease virus (NDV) strains are categorized as velogenic, mesogenic, and lentogenic primarily based on their pathotypes and virulence. ${ }^{10,11} \mathrm{ND}$ virulent strains are related to intense financial losses because of excessive morbidity 
and mortality, drop in egg-laying, and lesions in the upper respiratory and digestive tracts. ${ }^{12}$ It is a serious epizootic chicken disease in the low-earning food-deficit countries. It happens every year and kills on average $70 \%$ to $80 \%$ of the unvaccinated free-range indigenous chickens. ${ }^{13,14}$ It is endemic in Ethiopia with common outbreaks in the commercial, outdoor, and village chicken farms. ${ }^{15,16}$

Clinical diagnosis based on history, signs, and lesions further to hemagglutination and hemagglutination inhibition test, virus neutralization test, enzyme-linked immunosorbent test, plaque neutralization test and reverse transcription-polymerase chain reaction (RT-PCR) may be used for confirmation of the ND virus. ${ }^{13}$

Previous sero-epidemiological investigations in different parts of Ethiopia ${ }^{17,18}$ indicated the endemicity of ND in village chickens. Newcastle disease is one of the problems in village chickens in most parts of Ethiopia. ${ }^{19,20}$ In Ethiopia, NDV has been stated to be widespread because of fast expansion of the poultry industry, excessive stocking densities, and insufficient biosecurity measures which create situations conducive for the spread and maintenance of the endemicity of the disease. ${ }^{21}$

The disease is extensively distributed in the world and several countries such as Asia, Africa, Central America, and South America have endemic or common outbreaks due to virulent Newcastle Disease Virus (NDV) and there are sporadic outbreaks of the virus internationally. ${ }^{22}$ In worldwide spread, ND with low virulent strains is enzootic in Asia, Africa, Central America, and a part of South America, representing a permanent hazard to the poultry industry. The availability of serological test which is tailored to the conditions in these countries would facilitate diagnosis and accurate monitoring of vaccination programs. ${ }^{23}$

Despite the rampant outbreaks and the truth that ND represents the most intense chicken disease, epidemiological study regarding the disease specifically in BunoBedele zone are scarce. Continuous surveillance of the disease is important to take measures which includes appropriate control practices including vaccination of the susceptible chickens.

In line with this, the aim of the study is to determine the seroprevalence of Newcastle disease and its associated risk factors in non-vaccinated village chickens of the three selected districts of Buno bedele zone.

\section{Materials and Methods}

\section{Study Area}

The investigation was carried out in three districts (Didessa, Chora, and Gechi) of Buno Bedele zone.
Didessa district is one of the districts of Buno Bedele zone, Oromia National Regional State. Administratively the district is divided into 31 rural kebeles and one town. It is located at a distance of $60 \mathrm{Km}$ from the zonal town and $420 \mathrm{Km}$ from the capital Addis Ababa. Geographically, the Didessa district extends between $7^{\circ} 59^{\prime} 14^{\prime \prime}$ to $8^{\circ} 14^{\prime} 48^{\prime \prime}$ North and $36^{\circ} 16^{\prime} 56^{\prime \prime}$ up to $36^{\circ} 49^{\prime} 21^{\prime \prime}$ East. $^{24}$

Chora is one of the 21 districts of Buno Bedele zone in Oromia region. It is $515 \mathrm{~km}$ away from Addis Ababa on the main road to Bedele to Metu. This town has a longitude and latitude of $8^{\circ} 27^{\prime} \mathrm{N} 36^{\circ} 21^{\prime} \mathrm{E}$ and an elevation between $2012-$ 2162 meters (6601-7093 ft) above sea level. ${ }^{25}$

Gechi Woreda is found in Buno Bedele zone of Oromia Region, southwestern Ethiopia. It is located at a longitude and range of $8^{\circ} 27^{\prime} \mathrm{N} 36^{\circ} 21^{\prime} \mathrm{E}$ and $8.450^{\circ} \mathrm{N} 36.350^{\circ} \mathrm{E}$ respectively at approximately $462 \mathrm{~km}$ southwest of Addis Ababa. It is bordered on the south by Didessa, on the East by the Jimma, on the north by Bedele of Benishangul Gumuz Region, on the northeast the Didessa River which separates it from the East Wollega zone, on the southeast by Gechi. ${ }^{26}$

\section{Study Animals}

Domestic chickens were sampled with respect to factors including district, sex and age. The age was determined based on history from the owners (27), as young, adult, and old.

\section{Study Design}

The study was cross-sectional in its design. The purpose of the study was explained to the selected owners before sample collection. Didessa, Gechi, and Chora districts of Bedele zone were the involved study areas. Figure 1 indicates number of collected serum samples in each district of the study area.

\section{Sample Size Determinations}

A total of 480 serum samples were collected from randomly selected chickens. Initially three districts were selected from the zone. Three peasant associations were selected from each district using random sampling method. The sample size was decided using the Thrusfield formula $^{28}$ considering prevalence of ND in the study areas was $50 \%$, with a $95 \%$ confidence interval.

$$
N=\frac{1.96^{2}(p)(1-p)}{d^{2}}
$$

$\mathrm{N}=$ the needed sample size, $\mathrm{P} \exp =$ expected prevalence and $\mathrm{d}=$ desired absolute precision, $\mathrm{N}=384$. To increase 


\section{Number of Serum collected from each districts}

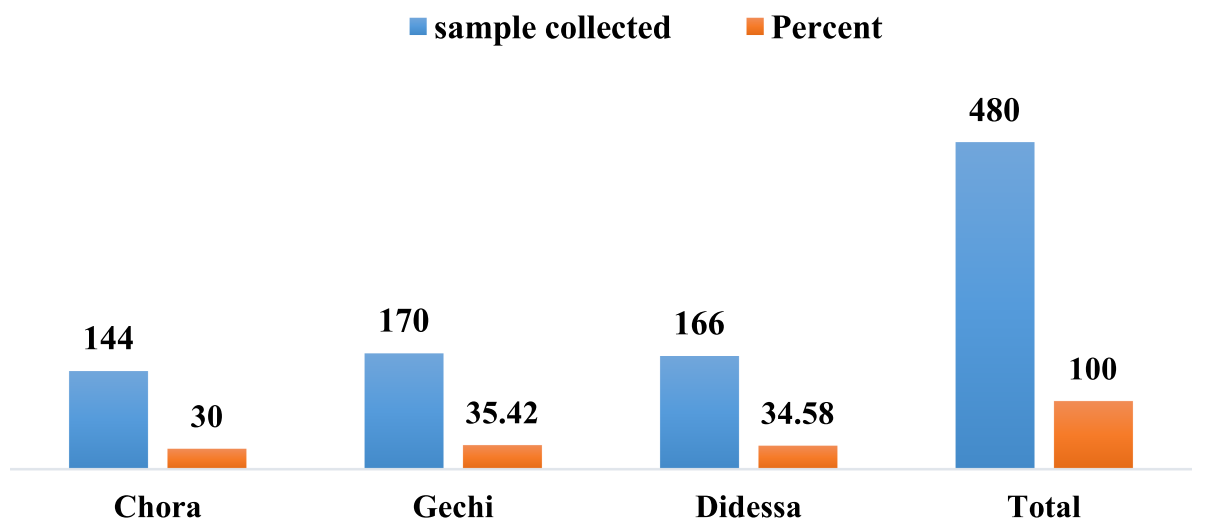

Figure I Number of serum samples collected in each district of the study area.

precision by $25 \%$, additional 96 backyard chickens were added. Hence 480 chickens were used for the study.

\section{Sample Collection and Laboratory Procedures}

After disinfecting the site, $2-3 \mathrm{~mL}$ of blood was collected from the brachial vein of chickens using a $5 \mathrm{~mL}$ syringe and a 23 gauge. Then, collected blood was labeled and allowed to clot overnight under normal atmospheric conditions. So, clear serum was harvested in labeled $2 \mathrm{~mL}$ cryovial tubes and stored at $-20^{\circ} \mathrm{C}$ until indirect ELISA was carried out. ${ }^{23}$

An indirect ELISA technique was carried out through the use of IDvet Innovative Diagnostics kits (Grabels, France): ID Screen ${ }^{\circledR}$ NDV Indirect. All the reagents were adapted to room temperature $\left(21 \pm 5^{\circ} \mathrm{C}\right)$ before use and homogenized afterward by inversion. The sera were diluted to $1 / 500$ th and then loaded to ELISA plates to start an immunosorbent reaction as per the manufacturer's manual. ELx800 spectrophotometer (BioTek ${ }^{\mathrm{TM}}$, USA) equipped with $450 \mathrm{~nm}$ filter where the measured optical density was transformed into titrated antibody read ELISA plates. The averages of the titers and the coefficient of variation $(\mathrm{CV})$ were automatically calculated by the band and by series of samples, with the software provided by the laboratory (Gen 5 1.11).

\section{Data Management and Analysis}

The data generated from the study were arranged, coded, and entered into an Excel spreadsheet (Microsoft ${ }^{\circledR}$ excel 2007). SPSS version 20 statistical software was used for analysis including Pearson's chi-squared test and logistic regression. Logistic regression analysis was done to determine association between the seroprevalence and associated risk factors. $\mathrm{P}$ value less than 0.05 indicated statistically significant differences.

\section{Results}

From the total 480 chickens' sera examined in three selected districts of Buno Bedele zone, 144 (30\%) of them were identified as positive for antibodies against NDV. The highest ND seroprevalence $(34.94 \%)$ was recorded in Didessa, followed by Gachi $(31.76 \%)$, and Chora (22.22\%). Table 1 indicates seroprevalance of Newcastle disease in the three districts of Buno Bedele zone.

Among the sex groups, a higher prevalence (31.6\%) was observed in female animals. Breed-wise, crossbreeds showed the highest level of ND seropositivity (36.8\%). Seroprevalence of Newcastle disease in association with other risk factors like breed, age, and sex, are shown in Table 2. In the cross- and local breeds of chickens, the prevalence was (34.37\%) and (9.74\%) respectively. Only breed showed statistically significant differences among risk factors computed in Buno Bedele zone. Association between risk factors and ND seropositivity was indicated in Table 2.

The logistic regression analysis identified that breed was statistically significant (Table 3). Cross-bred chickens were more likely to be infected by ND than local breeds (OR = $0.251,95 \%$ CI: $0.145-0.433)$. The risk of ND occurrence was also increased 0.607 times (OR $=0.607,95 \%$ CI: 0.33 01.117) in female animals than in males. The results also showed that the odds of infection were higher in old chickens than in young and adult chickens. Table 3 indicates logistic regression analysis of ND seropositivity with various risk factors. 
Table I Seroprevalance of Newcastle Disease in Districts of Buno Bedele Zone

\begin{tabular}{|c|c|c|c|c|c|c|}
\hline Zone & District & PA & $\begin{array}{l}\text { Total No of } \\
\text { Samples }\end{array}$ & $\begin{array}{l}\text { No of Positive } \\
\text { Samples }\end{array}$ & $\begin{array}{l}\text { No of Negative } \\
\text { Samples }\end{array}$ & $\begin{array}{l}\text { Prevalence } \\
\%\end{array}$ \\
\hline \multirow[t]{12}{*}{ Buno Bedele } & \multirow[t]{4}{*}{ Didessa } & Yembero & 56 & 23 & 33 & $41.07 \%$ \\
\hline & & Sineso & 60 & 22 & 38 & $36.67 \%$ \\
\hline & & Garado & 50 & 13 & 37 & $26 \%$ \\
\hline & & Total & 166 & 58 & 108 & $34.94 \%$ \\
\hline & \multirow[t]{4}{*}{ Chora } & Schickengela & 50 & 10 & 40 & $20 \%$ \\
\hline & & Aba Bora & 50 & 12 & 38 & $24 \%$ \\
\hline & & Hawa Yember & 44 & 10 & 34 & $22.72 \%$ \\
\hline & & Total & 144 & 32 & 112 & $22.22 \%$ \\
\hline & \multirow[t]{4}{*}{ Gachi } & Seko & 67 & 16 & 51 & $23.88 \%$ \\
\hline & & Gole Maya & 50 & 17 & 33 & $34 \%$ \\
\hline & & $\begin{array}{l}\text { Gachi 0I } \\
\text { Kebele }\end{array}$ & 53 & 21 & 32 & $39.62 \%$ \\
\hline & & Total & 170 & 54 & 116 & $31.76 \%$ \\
\hline & & & 480 & 144 & 336 & $30 \%$ \\
\hline
\end{tabular}

Note: $X^{2=} 491, P$-value $=0.005$.

Table 2 Association Between Risk Factors and ND Seropositivity

\begin{tabular}{|l|l|l|l|l|l|l|}
\hline \multicolumn{2}{|l|}{ Risk Factors } & No of Chickens Tested & Positive & $\%$ Positive & $\mathbf{X}^{2}$ & P-value \\
\hline Sex & Male & 78 & 17 & $21.8 \%$ & 2.5375 & 0.1112 \\
& Female & 402 & 127 & $31.6 \%$ & & \\
\hline \multirow{2}{*}{ Breed } & Local & 138 & 18 & $13.0 \%$ & 25.397 & $4.666 \mathrm{e}-07$ \\
& Cross & 342 & 126 & $36.8 \%$ & & \\
\hline \multirow{2}{*}{ Age } & Young & 80 & 25 & $31.2 \%$ & 1.9268 & 0.3816 \\
& Adult & 347 & 99 & $28.5 \%$ & & \\
& Old & 53 & 20 & $37.7 \%$ & & \\
\hline
\end{tabular}

Table 3 Logistic Regression Analysis of ND Seropositivity with Various Risk Factors

\begin{tabular}{|l|c|c|c|c|}
\hline Variables & Level of Variables & OR & Cl & P-value \\
\hline Sex & Female vs Male & 0.607 & $0.330-1.117$ & 0.1112 \\
Breed & Cross vs local & 0.251 & $0.145-0.433$ & $4.666 \mathrm{e}-07$ \\
Age & Young, Adult vs Old & 0.939 & $0.740-1.192$ & 0.3816 \\
\hline
\end{tabular}

Abbreviations: OR, odds ratio; $\mathrm{Cl}$, confidence interval.

Generally, the overall seroprevalence of ND showed that females [(31.59\%) 127/402] were more affected than males (21.79\%) 17/78), while breed-wise, cross-bre d [(36.84\%) 126/342] chickens were more affected than local breeds [(13.04\%) 18/138].

\section{Discussion}

The present study revealed circulating NDV in backyard chickens in different districts of Buno Bedele zone of Western Oromia, Ethiopia using indirect ELISA. The overall prevalence of ND in backyard chickens in this study was $30 \%$. 
The overall seroprevalence in this study was in close agreement with the findings of earlier studies in central Ethiopia at Debre Berhan which showed a prevalence of $28.57 \%{ }^{17}$ and $23.6 \%$ in the Delta State of Nigeria. ${ }^{29}$ However, the present findings were considerably lower than in the previous reports by Tadesse et $\mathrm{al}^{17}$ in which a seroprevalence of $32.2 \%$ was reported in central Ethiopia. On the other hand, the result of the present study was higher than the findings of other studies in Eastern Shewa Kersa kondaltity district and rift valley areas of Ethiopia where seroprevalence of 5.9\%, 5.6\%, and $11.61 \%$ was recorded respectively. ${ }^{6,30,31}$ So, the present study revealed that ND is endemic in the studied area and all PAs in the districts showed evidence of Newcastle disease in the laboratory tested sera. The variable seroprevalence rates ranging from $20 \%$ to $41.07 \%$ in this study agree with the findings of various researchers in Ethiopia. This finding was consistent with the previous study reports in different parts of Ethiopia, 12.9 to $47.6 \%$ in Southern and Rift valleys ${ }^{18}$ and $32.22 \%$ in the central part of Ethiopia. ${ }^{17}$ The prevalence varied across different study areas. From Buno Bedele zone selected districts, the highest prevalence was recorded at Didessa (34.94\%) and the lowest prevalence was recorded at Chora (22.22\%) district. In this study, the prevalence of ND antibodies for sex was determined and seroprevalence in female chickens was relatively higher $(31.6 \%)$ than in males $(21.8 \%)$ in Buno Bedele. The difference was not statistically significant $\left(x^{2}=2.5375\right.$; $\mathrm{P}$ value $=0.1112$ ). This result was similar to previous study findings reported in Ethiopia. ${ }^{18,27}$

From the study findings, female chickens were highly infected by NDV compared to male chickens. According to ${ }^{17,32-35}$ in Ethiopia, female chickens were more vulnerable to NDV compared to male chickens, which is consistent with this study. This could be because female chickens were mostly retained for long-term production purposes compared to the males which were mostly used for non-productive purposes (food, income, and socio-cultural or religious rites). The prevalence of NDV in different breeds was varied.

More cross-bred chickens [126 (36.84\%)] were positive than locally-bred [18 (13.04\%)] in Buno Bedele. There was a statistically significant difference $\left(x^{2}=25.397\right.$; $\mathrm{P}$-value $=4.466 \mathrm{e} 07)$. Regarding breed of chicken, it was higher (36.84\%) in cross-breeds than in local breeds (13.04\%). The variation could be multifactorial like management, season, unequal proportions of breeds sampled during sampling. ${ }^{36}$

Seroprevalence was also assessed by age and the difference in the seroprevalence between young and adult chickens was statistically insignificant $(p>0.05)$, which does not agree with the finding of Vui et $a l^{37}$ which stated that young chickens had a significantly lower NDV antibody titer than adults. Overall, in Buno Bedele, seroprevalence was high in old age chickens and this can be hypothesized to be due to more frequent exposure of older birds to field virus, which means they might have survived the disease at an earlier age. ${ }^{27}$

Female chickens were more likely to be infected with Newcastle disease virus (OR $=0.607 ; 95 \%$ CI: 0.330 1.117) than male chickens. Additionally, cross-bred chickens were more likely to be infected with Newcastle disease virus $(\mathrm{OR}=0.251 ; 95 \%$ CI: 0.145 $0.433)$ than locally-bred chickens. The overall variation of the findings might be due to variation in management system that may serve as a stress factor and favor infection. Poor sanitary conditions, continuous exposure of chickens to range conditions and wild birds, nutritional deficiencies, absence of vaccination in traditionally managed chickens, and contact of chickens of one village with those in other villages may facilitate the spread of ND. ${ }^{38}$ Generally, findings of this research indicated ND is a prevalent disease in the study area. Hence, attention should be paid to control ND prior to outbreaks.

\section{Conclusion and Recommendations}

Newcastle disease was successfully investigated in this study. Findings of seroprevalence among backyard chickens indicated that ND is a serious health problem. Overall seroprevalence of ND in this study was $30 \%$. The disease affected all age groups of chickens regardless of the differences in breed and sex. In conclusion, chickens are endemically infected with NDV in the study areas. Hence, detailed investigation coupled with molecular analysis should be conducted to assess the status of NDV infection and give insight for further investigations.

\section{Data Sharing Statement}

It is incorporated in the main text or article.

\section{Ethical Consideration}

The research was carried out with high regard for animal welfare and it was approved by Wollega University, Department of Veterinary Clinical Science.

\section{Acknowledgments}

We thank Bedele veterinary regional laboratory for their cooperation as well as permission for using laboratory facilities. The authors equally participated in this research, hence, there is no conflict of interest among researchers. 


\section{Funding}

No funding is associated with this work.

\section{Disclosure}

The authors report no conflicts of interest for this work.

\section{References}

1. Shapiro B, Gebru G, Desta S, et al. Ethiopia Livestock Master Plan. ILRI Project Report. Nairobi, Kenya: International Livestock Research Institute (ILRI); 2015.

2. Wubet W, Bitew M, Mamo G, et al. Evaluation of inactivated vaccine against fowl cholera developed from local isolates of Pasteurella multocida in Ethiopia. Afr J Microbiol Res. 2019;13(27):500-509.

3. Halima Hassen FWC, Naser TD, deRock A, Van Marle Koster E. Studies on the growth performance of native chicken ecotypes and RIR chicken under improved management system in North West Ethiopia. Livest Res Rural Dev. 2006;18(6):76

4. CSA (Central Statistical Agency). Agricultural Sample Survey 2009. Report on Livestock and Livestock Characteristics. Addis Ababa, Ethiopia. Vol. II; 2017. Statistical Bulletin No, 585

5. Al Mamun M, Mehetazul K. Occurrence of poultry diseases at Kishoregonj district of Bangladesh. MOJ Proteom Bioinform. 2019;8:7-12

6. Chaka H, Goutard F, Bisschop SP, Thompson PN. Seroprevalence of Newcastle disease and other infectious diseases in backyard chickens at markets in Eastern Shewa zone, Ethiopia. Poult Sci. 2012;91 (4):862-869. doi:10.3382/ps.2011-01906

7. Damena D, Fusaro A, Sombo M, et al. Characterization of Newcastle disease virus isolates obtained from outbreak cases in commercial chickens and wild pigeons in Ethiopia. Springerplus. 2016;5(1):476. doi:10.1186/s40064-016-2114-8

8. Mayo MA. A summary of the changes recently approved by ICTV. Arch Virol. 2002;147(8):1655-1656. doi:10.1007/s007050200039

9. Amarasinghe GK, Aréchiga Ceballos NG, Banyard AC, et al. Taxonomy of the order Mononegavirales: update. Arch Virol. 2018;163(8):2283-2294.

10. Brown VR, Bevins SN. A review of virulent Newcastle disease viruses in the United States and the role of wild birds in viral persistence and spread. Vet Res. 2017;48(1):68. doi:10.1186/s13567017-0475-9

11. Schirrmacher V. Immunobiology of new castle disease virus and its use for prophylactic vaccination in poultry and as adjuvant for therapeutic vaccination in cancer patients. Int $J$ Mol Sci. 2017;18 (5):1103. doi:10.3390/ijms 18051103

12. Alexander DJ, Senne DA. Newcastle disease. Dis Poult. 2003;11 (1):64-87.

13. Melkamu S, Asrat M. Review on economic importance and current diagnostic techniques of Newcastle disease in poultry. Int $j$ Adv Res Biol Sci. 2018;5(3):117-125.

14. Gueye EF. Newcastle disease in family poultry: prospects for its control through ethnoveterinary medicine. Dakar-Hann, Senegal; 2002.

15. Nwanta JA, Abdu PA, Ezema WS. Epidemiology, challenges and prospects for control of Newcastle disease in village poultry in Nigeria. World Poul Sci J. 2008;64(1):119-212. doi:10.1017/ S0043933907001766

16. Sa'idu L, Abdu PA. Outbreak of viscerotropic velogenic form of Newcastle disease in vaccinated six weeks old pullets. Sokoto $J$ Vet Sci. 2008;7:1.

17. Tadesse S, Aschickenafi A, Aschalew Z. Seroprevalence study of Newcastle disease in local chickens in central Ethiopia. Int J Appl Res Vet Med. 2005;3:25-29.
18. Zeleke A, Sori T, Gelaye E, Ayelet G. Newcastle disease in village chickens in the Southern and Rift Valley districts in Ethiopia. Intl J Poul Sci. 2005;4(7):507-510

19. Dessie T, Jobre Y. A review of the importance and control of new castle disease in Ethiopia. Ethiop Vet J. 2004;8(1):71-79.

20. Mazengia H. Review on major viral diseases of chickens reported in Ethiopia. J Infect Dis Immun. 2012;4(1):1-9.

21. Okwor and Eze Didacus. The annual prevalence of Newcastle disease in commercial chickens reared in South-Eastern Savannah Zone of Nigeria. Res J Poul Sci. 2010;3:23-26

22. OIE. Newcastle disease. In: OIE Manual of Standards for Diagnostic Tests Vaccines. 4th ed. Paris, France; 2009.

23. OIE (Office of International Epizootes). Newcastle disease. In: Manual of Diagnostic Tests and Vaccines for Terrestrial Animals. Paris, France; 2012. chapter 2. 3.14

24. CSA. National statistics archived November 23, 2006, at the way back machine; 2005.

25. CSA. Federal Democratic Republic of Ethiopia Central Statistics Authority. In: Agricultural Sample Survey. Vol. II. Report on Livestock and Livestock Characteristics. Statistical Bulletin. Addis Ababa, Ethiopia; 2014.

26. CSA (Population and Housing Census of Ethiopia). Results for Oromia Region; 2007. Vol. 1, Tables 2.1, 2.5, 3. Accessed January 15, 2021.

27. Belayheh G, Moses N, Melese K, Fufa B. Seroprevalence of Newcastle disease virus antibodies in village chickens in Kersana-kondalaity district, Ethiopia. Global Vet. 2014;12(3):426-430.

28. Thrusfield M. Veterinary Epidemiology. 2nd ed. Oxford: Blackwell Science; 2005:117-198

29. Abraham OJ, Sulaiman LK, Meseko CA, et al. Seroprevalence of Newcastle disease virus in local chicken in Udu local government area of Delta State, Nigeria. Int J Adv Agric Res. 2014;2:121-125.

30. Regasa C, Fufa D, Berihanu S, Hunduma D. Seroprevalence of Newcastle disease in backyard chickens in the mid rift valley of Oromia, Ethiopia. Poster presented at the 12th International Conference of the Association of Institutions for Tropical Veterinary Medicine; Montpellier, France; 2007:121.

31. Terefe D, Belaineh R, Chaka H, et al. Serological and molecular study of Newcastle disease virus in village chickens in selected Rift Valley Areas, Ethiopia. $J$ Vet Sci Technol. 2015;6(06):264. doi: 10.4172/2157-7579.1000264

32. Getachew B, Berihu H. Sero-prevalence of Newcastle disease and its associated risk factors in village chickens at Alamata District, Southern Tigray, Ethiopia. Int J Eng Develop Res. 2016;4(3):2016.

33. Tilahun S, Amare E, Asamanew T, Abebe G, Shimels M. Seroprevalence of Newcastle Disease in Backyard Chickens in Sebata Hawas District, Central Ethiopia. World Applied Sciences Journal. 2016;34(5):540-544. doi:10.5829/idosi.wasj.2016.34.5.10348

34. Ohore OG, Ozegbe PC, Emikpe BO, Okojie VE. Survey of antibodies to Newcastle disease virus in apparently healthy adult Nigerian indigenous chickens (Gallus domesticus) in Ibadan using Elisa. Afr J Clin Exper Microbiol. 2002;3(1):38-40. doi:10.4314/ajcem.v3i1.7350

35. Sadiq MA, Nwanta JA, Okolocha EC, Tijjami AN. Retrospective (2002-2009) study of Newcastle disease (ND) cases in avian species in Maiduguri, Borno State, North-Eastern Nigeria. Intl $J$ PoulSci. 2011;10(1):76-81. doi:10.3923/ijps.2011.76.81

36. Geresu MA, Elemo KK, Kassa GM. Newcastle disease: seroprevalence and associated risk factors in the backyard and small scale chicken producer farms in Agarfa and Sinana Districts of Bale zone, Ethiopia. J Vet Med Animal Health. 2016;8(8):99-106.

37. Vui TQ, Lohr JE, Kyule MN, Zessin KH, Baumann MP. Antibody Levels against Newcastle disease virus, infectious Bursal disease virus and Avian influenza virus in rural chickens in Vietnam. Intl J PoulSci. 2002;1(5):127-132. doi:10.3923/ijps.2002.127.132

38. Habte T, Amare A, Bettridge J, Collins M, Christley R, Wigley P. Guide to Chicken Health and Management in Ethiopia. ILRI Manual 25. Nairobi, Kenya: International Livestock Research Institute (ILR); 2017. 


\section{Publish your work in this journal}

Veterinary Medicine: Research and Reports is an international, peerreviewed, open access journal publishing original research, case reports, editorials, reviews and commentaries on all areas of veterinary medicine. The manuscript management system is completely online and includes a very quick and fair peer-review system. Visit http://www.dovepress.com/testimonials.php to read real quotes from published authors.

Submit your manuscript here: http://www.dovepress.com/veterinary-medicine-research-and-reports-journal 